\title{
TELEMEDICINE AS AN EFFORT TO IMPROVE PUBLIC KNOWLEDGE TO FIGHT COVID-19 PANDEMIC
}

\section{Sacharissa Zerlina Tsarwah Thirafi ${ }^{1}$, Triadi Putra Paladan ${ }^{1}$, Bonfilio Neltio Ariobimo ${ }^{1}$, Barizatul Husniyah ${ }^{1}$, Monica Tiara Arum Kinanthi ${ }^{1}$, Gusti Agung Ayu Ira Kencana Dewi $^{1}$, Prima Ardiansah Surya ${ }^{1}$, Yolanda Ayu Yashinta ${ }^{1}$, Zaufy Verlieza Oktaviano Subagyo ${ }^{1}$, Laksmi Wulandari², Linda Dewanti*3 ${ }^{2}$}

${ }^{1}$ Faculty of Medicine, Universitas Airlangga, Indonesia, ${ }^{2}$ Department of Pulmonology and Respiratory Medicine, Faculty of Medicine, Universitas Airlangga, Dr Soetomo General Academic Hospital, Indonesia, ${ }^{3}$ Department of Public Health-Preventive Medicine, Faculty of Medicine, Universitas Airlangga, Indonesia

\begin{abstract}
$\frac{\text { ABSTRACT }}{\text { The role of the community is an essential part to cut down the }}$ COVID-19 chain transmission, a current world pandemic. Knowledge determines a person's healthy behavior that can prevent transmission of COVID-19. This research's goal is to analyze the effect of health promotion via telemedicine on increasing knowledge about COVID-19 prevention in the productive-age population in Indonesia. This study used one group pretest-posttest design and accidental sampling method involving 146 respondents based on the inclusion criteria. The data collection method was carried out by using a questionnaire containing simple and general questions related to COVID-19 that tested subjects before and after telemedicine health promotion. Based on the assessment of the questionnaire through pretest and posttest, there was an increase in the average knowledge after being given health education with telemedicine with $p<0.001$ (CI 95\%). This study shows that telemedicine could significantly increase average knowledge about COVID-19 prevention in the productive-age population in Indonesia.
\end{abstract}

\section{ARTICLE HISTORY}

Received: September 6, 2020 Revised: November 11, 2020 Accepted: March 29, 2021 Published: June 30, 2021 (Online)

doi: 10.20473/jcmphr.v2i1.21883

\section{KEYWORDS}

COVID-19; telemedicine; health promotion; knowledge; virus

\section{CORRESPONDING}

AUTHOR

Linda Dewanti

$\triangle$ lindaperisdiono@yahoo.com

Department of Public HealthPreventive Medicine, Faculty of Medicine, Universitas Airlangga, Jl. Mayjend Prof. Dr. Moestopo 47, Surabaya, Indonesia

\section{INTRODUCTION}

Coronavirus Disease (COVID-19) is an infectious disease caused by the SARS-CoV2 type coronavirus. ${ }^{1}$ After approximately one month from the first discovery of the first patient in Wuhan, Hubei Province, China, ${ }^{2}$ this disease spread to other countries until finally declared as a pandemic by WHO. ${ }^{1}$ To cut down the COVID-19 chain transmission, various strategies have been done by each affected country (188 countries) including Indonesia. $^{3}$
Germany, which has a superior ratio for intensive care beds and the number of doctors per population compared to their neighboring countries, already had a strong initial source at the start of the pandemic. The fast action of the German government to carry out a mass rt-PCR per confirmed case examination has been followed by several other countries such as Australia, New Zealand, Russia, and others, and related to positive impact in accelerating COVID-19 pandemic recovery. With a strategy of self-discipline, careful 
calculations, and more than the adequate implementation of the rt-PCR, South Korea has successfully emerged from this pandemic problem without having to undertake a major lock-down in a relatively short time. One of the South Korean success strategies is dayby-day up to date information about COVID19 guides through various web and mobilebased applications that are continuously available to all levels of society. ${ }^{4}$

Indonesia, which is the world's largest archipelago state, with the world's $4^{\text {th }}$ largest population, and an average of 12.9 years of schooling $^{5}$ has many obstacles in disseminating and disciplining the wider community to cut down the COVID-19 chain transmission, besides the minimal availability of rt-PCR. The fact, although schools have been transferred to homes, the activities that caused people to be gathered have not been maximally suppressed. Especially Surabaya (which has been implemented three times during the massive social limitation period) and East Java are now considered the new epicenter after the new cases of COVID-19 in Jakarta and West Java have begun to be stabilized.

\section{MATERIALS AND METHODS}

This study has received ethical clearance from the Ethics Committee of the Faculty of Medicine, Universitas Airlangga. Research members offered to conduct education and discussion about COVID-19 on social media groups (Line, Whatsapp), then after agreement with another group members, an open invitation was made in the group to conduct socialization and discussion about COVID-19, the used media, and link address (Zoom, Google Meet). Before and after the
D-Day of the socialization, a pretest and posttest were carried out for each participant. The socialization was guided by a moderator to ensure the rundown of the event according to the agreed procedures. After the presentation/socialization, the moderator gave a chance for participants to ask questions related to the material and manage the discussion session until the event was over or there were no more questions. The questionnaire for the pretest and posttest had been tested for validity and reliability. Processing and data analysis using the SPSS application.

\section{RESULTS}

Total 146 respondents met the inclusion criteria. Most of the respondents are women (67.8\%), mostly with advanced (college/equivalent) education level (82.9\%), most professions as college students (39\%), and having an average age of 23 years old (SD 5.451). The average knowledge level of respondents about COVID-19 before being counseled shows that more than $50 \%$ of respondents are good $(80.1 \%)$, and those who have a poor knowledge level about COVID19 are 20 respondents (13.7\%), whereas after being counseled shows that the good knowledge level about COVID-19 is 136 respondents (93.2\%), and poor knowledge level is 7 respondents $(4.8 \%)$. The average pretest score of respondents was 80.99 (SD 18.589), while the average posttest score of respondents was 89.06 (SD 13.361). Many respondents answered incorrectly in the pretest questions related to suspected cases of COVID-19, how to kill the virus on the object's surface, and groups at high risk of COVID-19 infection. 
Table 1. Characteristics of Respondents

\begin{tabular}{cll}
\hline Characteristic & \multicolumn{1}{c}{ Category } & \multicolumn{1}{c}{ n (\%) } \\
\hline Gender & Female & $99(67.8)$ \\
& Male & $47(32.2)$ \\
& Total & $146(100)$ \\
\hline Education & Middle (High school) & $25(17.1)$ \\
& Advanced (College/equivalent) & $121(82.9)$ \\
& Total & $146(100)$ \\
\hline Profession & Unemployed & $13(8.9)$ \\
& College student & $57(39)$ \\
& Teacher & $5(3.42)$ \\
& Government Employ & $5(3.42)$ \\
& Private Employee & $38(26.02)$ \\
& Entrepreneur & $9(6.16)$ \\
& Police/soldier & $2(1.36)$ \\
& Housewife & $5(3.42)$ \\
& Others & $12(8.21)$ \\
Age & Total & $146(100)$ \\
\hline
\end{tabular}

Table 2. Knowledge Levels Distribution

\begin{tabular}{lll}
\hline $\begin{array}{c}\text { Knowledge } \\
\text { Level }\end{array}$ & \multicolumn{1}{c}{$\begin{array}{c}\text { Pretest n } \\
(\mathbf{\%})\end{array}$} & $\begin{array}{c}\text { Posttest n } \\
(\mathbf{\%})\end{array}$ \\
\hline Good & $117(80.1)$ & $136(93.2)$ \\
Middle & $9(6.2)$ & $3(2.1)$ \\
Poor & $20(13.7)$ & $7(4.8)$ \\
Total & $146(100)$ & $146(100)$ \\
\hline
\end{tabular}

Note: Good=Score more than 74; Middle=Score 56-74; Poor=Score less than 56

The average level of knowledge gained after the implementation of health promotion with telemedicine is higher than before the implementation of education. Table 3 showed that $p<0.001$ (with $\alpha=0.05$ ), which means that there is a significant association between the implementation of education with telemedicine toward the knowledge level of respondents.

Table 3. Effects of Health Education with Telemedicine on Knowledge Levels

\begin{tabular}{cccc}
\hline Variable & Mean rank & Sig. & \multicolumn{1}{c}{ Conclusion } \\
\hline Pretest & 44.41 & 0.0001 & There is significant \\
Posttest & 72.45 & & different between group \\
\hline \multicolumn{4}{c}{ Note: Wilcoxon test }
\end{tabular}

After the delivery of education, respondents were allowed to ask. There were 70 questions asked during the telemedicine session. The most frequently asked question is whether someone who has been infected with the COVID-19 virus can be re-infected.

\section{DISCUSSION}

Public compliance with the procedure to stop COVID-19 from spreading is very important, which is largely influenced by their 
knowledge of, and attitudes towards COVID19.5,6 Lessons learned from the SARS outbreak in 2003 show that knowledge and attitudes are critical to the incidence of infectious diseases associated with high levels of panic, which can further complicate efforts to prevent the spread of the disease. ${ }^{7,8}$

During the COVID-19 pandemic, to maintain physical distance, information about COVID-19 socialization is an important effort to prevent transmission of this disease, the most appropriate way is through social media in gathering target groups and using telemedicine in delivering educational materials. These program targets are social media groups (Line, Whatsapp) whose members are high school and college graduates, who are expected to be able to become "agents of change" after participating in this telemedicine. These people will be motivated to spread knowledge to other groups. With the increase in knowledge related to COVID-19, the community is expected to be able to cut down COVID-19 chain transmission. This is in line with the research of Zhong et al (2020) which states that the high level of public knowledge about COVID-19 is because $82.4 \%$ of the study sample came from college graduates which produced significant results between education level and public knowledge level about COVID-19. This is could happen because groups in this population are actively learning about this infectious disease from various information channels such as CCTV, the official website of the Chinese National Health Commission, and the official WeChat account of the Wuhan Health Commission. ${ }^{9}$

The results showed that there was a significant difference in knowledge between the research subjects before and after being given health education with telemedicine $(p=0.0001)$. The results showed that the "good" score on the questionnaire increased from 117 people $(80.1 \%)$ before being given health education with telemedicine to 136 people $(93.2 \%)$ after being given health education with telemedicine. This is following the statement of Peyravi et al (2020) which states that the rapid publication of messages generated from cyberspace and the high number of visitors reflects the effective and timely use of cyberspace to solve health problems. ${ }^{10}$ New educational technologies and the capacity of media must also be taken into account. Simple, functional, free online courses should be available to everyone; illiterate and disabled users should also be considered. Training improves public preparedness and appropriate responses to viruses. So, to manage the virus, policymakers in the health system, and all organizations involved must take steps to provide innovative, integrated, and applied educational content for everyone.

\section{CONCLUSION}

From this research, it can be concluded that there is a significant effect of health education via telemedicine on increasing average knowledge about COVID-19 prevention efforts in the productive-age population in Indonesia.

\section{ACKNOWLEDGMENT}

The authors thank the Faculty of Medicine Universitas Airlangga for allowing the authors to conduct this research. 


\section{REFERENCES}

1. World Health Organization (2020). Naming the coronavirus disease (COVID-19) and the virus that causes it. World Health Organization. Available at https://www.who.int/ emergencies/diseases/novel-corona virus-2019/technical-guidance/naming the-coronavirus-disease-(covid-2019) and-the-virus-that-causes-it. Accessed August 16, 2020

2. Rothan HA, Byrareddy SN (2020). The epidemiology and pathogenesis of coronavirus disease (COVID-19) outbreak. J Autoimmun, 109, https:// doi.org/10.1016/j.jaut.2020.102433

3. John Hopkins University and Medicine (2020). COVID-19 map. Available at https://coronavirus.jhu.edu/map.html. Accessed August 19, 2020

4. United Nations (2020). First person: South Korea's COVID-19 success story. UN News. Available at https:// news.un.org/en/story/2020/05/1063112. Accessed August 21, 2020

5. United Nations Development Programme (2016). Human Development Report 2016: Human Development for Everyone. United Nations Development Programme, 286.
Available at http://hdr.undp.org/ sites/ default/files/2016_human_development report.pdf. Accessed August 22, 2020

6. Tachfouti N, Slama K, Berraho M, et al (2012). The impact of knowledge and attitudes on adherence to tuberculosis treatment: A case-control study in a moroccan region. Pan Afr Med J, 12. Available at https://www.ncbi.nlm.nih. gov/pmc/articles/PMC3428172/pdf/PA MJ-12-52.pdf. Accessed at August 23, 2020

7. Person B, Sy F, Holton K, et al (2004). Fear and Stigma: The Epidemic within the SARS Outbreak. Emerg Infect Dis, 10(2), 358-363

8. Tao, N (2003). An analysis on reasons of SARS-induced psychological panic among students. J Anhui Inst Educ, 21(2), 78-79

9. Zhong BL, Luo W, Li HM, et al (2020). Knowledge, attitudes, and practices towards COVID-19 among chinese residents during the rapid rise period of the COVID-19 outbreak: A quick online cross-sectional survey. Int J Biol Sci, 16(10), 1745-1752

10. Peyravi M, Ahmadi Marzaleh M, Shamspour N, et al (2020). Public Education and Electronic Awareness of the New Coronavirus (COVID-19): Experiences from Iran. Disaster Med Public Health Prep, 14(3), e5-e6 